\title{
Ekologiczne aspekty katolickiej teologii moralnej
}

\begin{abstract}
Wstęp
Ekologiczny aspekt katolickiej teologii moralnej, nie powinien wzbudzać zdziwienia, ponieważ nie jest to jakaś dziwna hybryda, która powstała wskutek sztucznych zabiegów mających na celu dowartościowanie ekologii autorytetem chrześcijańskiej tradycji. Wypowiedzi papieży na temat potrzeby ochrony środowiska przyrodniczego zdają się świadczyć na niekorzyść takiego zarzutu i pokazują tylko doniosłość i potrzebę wdrażania w świadomość chrześcijanina potrzeby odpowiedzialnego i umiarkowanego korzystania $z$ zasobów ziemskich.

Praktyczne problemy etyczne $\mathrm{w}$ aspekcie ekologicznym, w moim artykule zacząłem przedstawiać od prawa naturalnego, które jest wyznacznikiem moralnego Bożego ładu w świecie - również w wymiarze ekologicznym. Następnie podjąłem problematykę sumienia ekologicznego, które jest „stróżem” moralności również w stosunku do ludzkich zachowań w środowisku przyrodniczym. Stara się ochronić człowieka przed popełnieniem grzechu ekologicznego, który przecież jest także jedna $\mathrm{z}$ form nieposłuszeństwa wobec Boga. Te ekologiczne aspekty teologii moralnej pozostaną jednak pustymi słowami jeśli nie będziemy upowszechniać ich w edukacji ekologicznej. Bardzo ważne jest również kształtowanie odpowiednich trwałych postaw wobec drugiego człowieka i przyrody cechujących się miłością, roztropnościa i umiarkowaniem, jak uczy nas aretologia (nauka o cnotach moralnych). Na zakończenie tego paragrafu umieściłem Dekalog ekologiczny, którego zasadom chrześcijanie powinni hołdować w codziennym życiu.
\end{abstract}

\section{Prawo naturalne w płaszczyźnie ekologicznej}

Jak zauważył ks. Tadeusz Ślipko „Można by sporządzić długą listę uczonych, którzy bądź przeczą istnieniu tego rodzaju prawa, bądź redu-

\footnotetext{
Instytut Nauk Spolecznych, Wydzial Humanistyczny Akademii Podlaskie w Siedlcach.
} 
kują je do pewnego zespołu ogólnych ideałów etycznych pozbawionych wszakże kategorycznej mocy moralnego nakazu zobowiązującego osoby ludzkie do odpowiedniego działania, a już zgoła bez znaczenia dla prawdotwórczych organów władzy państwowej. Najbardziej zaś uderzające jest to, że dla wielu, w tym również katolickich autorów, kamieniem obrazy jest pluralizm filozoficzno - etycznych koncepcji prawa naturalnego, szczególnie zaś centralnego $\mathrm{w}$ nim pojęcia natury. A więc, jak tu rozprawiać o prawie naturalnym, a tym bardziej - doszukiwać się w nim podstawy szacunku dla życia i przyrody?"1.

Jednakże zdaniem tego uczonego sprawa nie przedstawia się beznadziejnie, gdyż „Pluralizm teorii i poglądów nie obciąża hipoteki samej tylko doktryny prawa naturalnego. Ten sam stan rzeczy daje się zauważyć $w$ wielu innych dyscyplinach naukowych. Ale też wielość teorii i definicji prawa naturalnego stanowi tylko wyzwanie i wezwanie do gruntowniejszego przemyślenia i krytycznej analizy prezentowanych w literaturze przedmiotu koncepcji ${ }^{2}$, aby tą drogą dojść do ustalenia stanowiska, które by można uznać za wyraz filozoficzno - etycznej prawdy"3.

Personalistyczne ujęcie prawa naturalnego $w$ płaszczyźnie ekologicznej, podkreśla, że pomimo faktu, że człowieka i resztę organizmów przyrodniczych łączy te same materialne podłoże, to tworzą jednak dwa odrębne światy. Człowiek żyje w przyrodzie, z przyrodą i dzięki niej, ale nie jest bez reszty przyroda, ponieważ ją przerasta, a więc $w$ pewnym sensie jest "poza przyroda»""4.

Mieczysław Ozorowski podkreśla, że treści moralnego prawa naturalnego oscylują wokół człowieka, zwłaszcza jego godności, życia, szeroko pojętej twórczości, religijności oraz społecznego wymiaru bytowania które mają również wymiar ekologiczny. Płaszczyzna takiego podejścia zasadza się na założeniu, że świat stworzony przez Boga nie jest przypadkiem i chaosem, i nawet dla ateisty, który co prawda nie wierzy w Boga, lecz przyjmuje istnienie porządku w świecie, wystarcza do uznania przez niego prawa moralnego, które również nakazuje dbać o wszystkie elementy, które tworzą środowisko społeczno - przyrodnicze ${ }^{5}$.

1 T. ŚLIPKO, Prawo naturalne jako podstawa szacunku czlowieka dla życia i przyrody, „Ethos" nr 25/26, 1994, s. 88.

2 Niestety ograniczone ramy artykułu nie pozwalają mi w całości podjąć obronę teorii prawa naturalnego. W sposób syntetyczny i przekonywujący dokonał tego T. ŚLIPKO, Zarys etyki ogólnej, Kraków 2002, s. 282-284.

3 T. ŚLIPKO, Prawo naturalne jako podstawa szacunku czlowieka dla życia i przyrody, op cit., s. 88.

4 Ibidem, s. 89.

5 M. OZOROWSKI, Teologiczne podstawy kultury ekologicznej, w: Podstaw'y kultury ekologicznej. Pod red. J. M. Dołęgi, Warszawa 2002, s. 45. 
W opinii tego teologa moralne prawo naturalne przypomina, że dopiero rozumowe rozpoznanie prawa warunkuje jego zaistnienie. Tak też się stało $\mathrm{w}$ latach pięćdziesiątych ubiegłego stulecia, kiedy człowiek uświadomił sobie rozmiary zniszczonego przez jego działalność środowiska. "Wówczas nastąpiło rozpoznanie prawa ochrony środowiska naturalnego człowieka, wynikającego z prawa moralnego: nie zabijaj. Rozpoznawanie to jest procesem ciągłym, dziejącym się na naszych oczach. Ponadto prawo moralne jest niezmienne, bo tkwi w niezmienności natury ludzkiej. Rozwój myśli ludzkiej powinien prowadzić do zmiany naszego podejścia ekologicznego wobec otaczającej nas rzeczywistości, jaką jest środowisko naturalne", niszcząc bowiem przyrodę, niszczymy również zakotwiczonego w niej czlowieka.

O ile prawo naturalne jest wyznacznikiem ładu moralnego, o tyle sumienie jest stróżem moralności również w wymiarze ekologicznym.

\section{Ekologiczne ujęcie syneidesjologii (nauki o sumieniu)}

Pojęcie sumienia ekologicznego zostało wprowadzone w obieg idei humanizmu ekologicznego przez ekologa - leśnika Aldo Leopolda pod koniec lat czterdziestych $X X$ wieku. W Polsce natomiast spopularyzowal je Julian Aleksandrowicz ${ }^{6}$ w swojej monografii na ten temat, a także na łamach wielu artykułów i referatów. Pomimo tego, iż publikacje z tego zakresu zapewniły mu poczesne miejsce w annałach humanistycznej refleksji ekologicznej, to niestety nie przyczyniły się do precyzacji samego pojęcia sumienia ekologicznego. Aleksandrowicz w swoich publikacjach nie zdefiniował tego pojęcia, używając go w wielu kontekstach, bazując na intuicyjnym i latwym odbiorze ${ }^{7}$.

Jak słusznie zauważył Andrzej Papuziński, w związku z taką sytuacją pojęcie sumienia ekologicznego używane jest w różnych kontekstach, w zależności czy stosujemy je odnośnie etyki środowiskowej, edukacji ekologicznej czy świadomości ekologicznej. W etyce środowiskowej termin ten rozumiany jest jako właściwa człowiekowi wewnętrzna instancja moralna, która pozwala człowiekowi rozstrzygnąć o moralnej słuszności postępowania mogącego wywołać zmiany w środowisku naturalnym. $\mathrm{Na}-$ tomiast w edukacji ekologicznej jest jednym z jej dwóch głównych celów, bowiem oprócz intelektualnej zdolności postrzegania przyrody jako wartości i dostrzegania skutków własnych działań, to przede wszystkim dołącza tu cel rozbudzenia wrażliwości człowieka wobec środowiska natu-

\footnotetext{
J. ALEKSANDROWICZ, Sumienie ekologiczne, Warszawa 1979.

A. PAPUZIŃSKI, Polityka a perspektywy sumienia ekologicznego, w: Ziemia domem cztowieka. Pod red. L. Krakowiaka, Warszawa 1997, s. 21.
} 
ralnego. $W$ przypadku świadomości ekologicznej chodzi przede wszystkim o internalizację teoretycznych treści, tak aby doprowadzić do trwałej więzi między akceptacją i respektowaniem odpowiednich przekonań, norm i wartości ekologicznych . $^{8}$

Papuziński definiuje sumienie ekologiczne ,jako ów moment $w$ doświadczeniu wolności przez człowieka, w którym uświadamia on sobie odpowiedzialność za życie w każdej postaci: antroposferę, zoosferę, biosferę i geosferę; za cały potencjał genetyczny życia na naszej planecie, za utrzymanie liczebności populacji wszystkich form życia, przynajmniej zapewniajacej ich przetrwanie $\mathrm{w}$ naturalnych warunkach i za nienaruszoną równowagę procesów naturalnych" 9 .

Należy przy tym podkreślić, iż Katechizm Kościoła katolickiego podkreśla konieczność wychowania sumienia, ponieważ „Od najmłodszych lat wprowadza ono dziecko $w$ poznawanie i praktykowanie prawa wewnętrznego, rozpoznawanego przez sumienie. Roztropne wychowanie kształtuje cnoty; chroni lub uwalnia od strachu, egoizmu i pychy, fałszywego poczucia winy i dążeń do upodobania $w$ sobie, zrodzonego $z$ ludzkich słabości i błędów. Wychowanie sumienia zapewnia wolność i prowadzi do pokoju serca"10.

W takim właśnie kontekście należy również mówić o sumieniu ekologicznym i potrzebie jego kształtowania, wychowania na gruncie chrześcijańskim. Jest to możliwe, ponieważ z punktu widzenia chrześcijańskiej etyki ekologicznej niszczenie środowiska jest czynem, który zasmuca Boga. Teolodzy, etycy i pedagodzy - katecheci katoliccy, którzy podejmują problematykę sumienia ekologicznego, skłaniają do refleksji, czy możemy z całą pewnością powiedzieć, że „nie mamy na sumieniu niczyjego życia" (Dz 20, 26).

Konieczny i aktualny jest więc postulat odpowiedniego - ekologicznego rachunku sumienia, który ma na celu uświadomić chrześcijaninowi - i w ogóle każdemu człowiekowi bez względu na wyznawaną religię czy światopogląd - czy jego stosunek do środowiska społeczno - przyrodniczego sprzyja jego zachowaniu i pozytywnej równowadze, czy w sposób niemoralny przyczynia się do jego dewastacji.

Warto nadmienić, iż w naszym kraju opracowano dwa wzory ekologicznych rachunków sumienia ${ }^{11}$.

Sumienie ekologiczne stara się ochronić człowieka przed popełnieniem grzechu przeciwko przyrodzie i bliźniemu, który w niej przecież egzystuje.

\footnotetext{
Ibidem, s. 21-22.

9 Ibidem.

10) Katechizm Kościota Katolickiego, Poznań 1994, n. 1784.

11 Por. J.W. CZARTOSZEWSKI, Ekologiczne rachunki sumienia, w: Ochrona środowiska w" filozofii i teologii. Pod red. J. M. Dołęgi i J. W. Czartoszewskiego, Warszawa 1999.
} 


\section{Grzech ekologiczny}

Definicja grzechu w KKK sformułowana została w następujący sposób: „Grzech jest wykroczeniem przeciw rozumowi, prawdzie, prawemu sumieniu; jest brakiem prawdziwej miłości względem Boga i bliźniego z powodu niewłaściwego przywiązania do pewnych dóbr. Rani on naturę człowieka i godzi w ludzką solidarność. Został określony jako "słowo", czyn lub pragnienie przeciwne prawu wiecznemu"12.

$\mathrm{Na}$ ogót problem grzechu ekologicznego rozpatrywany jest w nawiązaniu do przesłania biblijnego, że Bóg stworzył świat doskonały, wszystko było w nim dobre, w tym również człowiek, zwłaszcza jego kondycja moralna. Dopiero grzech zniweczył ten stan harmonii. Nie dostrzegając piękna przyrody - jako daru Boga dla ludzi - przyczyniając się do jej dewastacji, popełniamy grzech, albowiem złe uczynki wobec przyrody są grzechem popelnionym $w$ stosunku do Boga ${ }^{13}$.

Na płaszczyźnie teologiczno - moralnej analizy grzechu ekologicznego dokonał Jerzy Bajda ${ }^{14}$.

Uczony ten, specyfikę grzechu ekologicznego ujmuje w kategoriach ludzkiego nieposłuszeństwa wobec Boga jako stwórcy świata i jego porządku, w tym również i człowieka. Dzieje się tak dlatego, że „porządek ekologiczny należy do integralnej prawdy porządku naturalnego i że stosunek człowieka do środowiska życia $w$ najszerszym znaczeniu jest regulowany nakazami prawa naturalnego. Chodzi tu nie tylko o "prawo natury» rozumiane jako prawo stworzonego bytu, lecz przede wszystkim o moralne prawo naturalne, odnoszące się do człowieka tak w sensie podmiotowym jak przedmiotowym"15.

Biorąc pod uwagę fakt, że świat człowieka - osoby oraz świat przyrody wzajemnie się przenikają, za grzech ekologiczny należy uznać "to, co atakuje człowieka jako podmiot życia (gdyż osobowa synteza bytu streszcza w sobie wszystkie prawa świata stworzonego), a także to, co obniża i niszczy jakość świata jako środowiska życia (gdyż wewnętrzna logika świata i prawda rzeczy stworzonych jest skierowana ku czlowiekowi i podporządkowana jego powołaniu). (...) Ponieważ działania przeciwne środowisku (wykraczające poza rozumną miarę korzystania $z$ dóbr

12 Katechizm Kościota Katolickiego, op. cit., n. 1849.

13 Grzeszgc wobec przyrody odwracamy się od Boga, w: Katechezy ekologiczne. Pod red. S. Zięby, Lublin 1993, s. 149.

14 Por. J. BAJDA, Grzech ekologiczny (Próba podejścia do zagadnienia), w: Z człon'iekiem i przyroda (wreszcie) po ludzku. Pod red. B. Wójtkiewicz, Wisełka 1995, s.71-80; J. BAJDA, Grzech ekologiczny, w: Ochrona środow'iska w' filozofii i teologii. Pod red. J. M. Dołęgi, J. W. Czartoszewskiego, Warszawa 1999, s. 222-242.

15

J. BAJDA, Grzech ekologiczny, op. cit., s. 222-221. 
świata) są zawsze w jakimś stopniu formą zaatakowania życia, dlatego musi się je uważać za działania wykluczone powaga V Przykazania Dekalogu" ${ }^{\prime \prime 6}$.

Pojęcie grzechu ekologicznego zakłada więc, że istnieje porządek ustalony przez Boga, w którym określono prawdę i przeznaczenie wszystkich stworzeń, zaś człowiek zobowiązany jest moralnie wypełniać ten plan. Możliwość popełnienia grzechu ekologicznego wynika więc z faktu, że na człowieku spoczywa unikatowa odpowiedzialność za świat na podstawie powolania stwórczego, jakie jest zawarte w Księdze Rodzaju. Człowiek jest jakby namiestnikiem Boga w świecie przyrody, w którym sprawuje władzę na mocy Bożego mandatu. Nie może jednak człowiek przypisywać sobie boskości (czy jakiemuś innemu stworzeniu), gdyż w Biblii nie ma mowy o absolutnym wladztwie człowieka, lecz o takim używaniu ziemi, które ogólnie wynika z ogólnego powołania ludzkości jako "rodziny Bożej»"17.

$\mathrm{Na}$ podstawie powyższych uwag J. Bajda przedstawia istotę grzechu ekologicznego, nawiązując przy tym do Biblii, podkreślając przy tym, że „grzech ukazany na kartach Biblii ma zarazem swoją postać «ekologiczną", można powiedzieć, że grzech jako taki jest także ze swej istoty i z konieczności grzechem ekologicznym, jest złem, które burzy ludzki świat. Burzy bowiem cały porządek stworzonego bytu, harmonię człowieka i świata, burzy jedność wspólnoty ludzkiej, owszem, jedność w samej osobie ludzkiej, wreszcie wnosi swój burzycielski ferment w całą strukturę życia i świata"18.

Ponadto grzech ekologiczny ma swój wymiar chrystocentryczny, albowiem jest także grzechem przeciw odkupieniu, a więc jest odrzuceniem Chrystusa. Jest to podyktowane tym, że grzech ekologiczny „wynika $\mathrm{z}$ rozpaczliwego przekonania, że świat nie ma swojej przyszłości i że należy zeń wyrabować wszystko, co się da, zanim się nie zapadnie w nicość"19. Aby się jednak tak nie stało ważne jest kształtowanie u chrześcijanina odpowiednich sprawności moralnych, mających na celu poszanowanie środowiska społeczno - przyrodniczego.

\section{Ekologiczne aspekty aretologii (nauki o cnotach moralnych)}

W teologii moralnej podkreśla się przy tym, że aretologia zawiera w sobie charakterystykę poszczególnych cnót teologicznych (teologalnych) i kardynalnych. W tej pierwszej grupie wymienia się główne cnoty chrze-

\footnotetext{
16 Ibidem, s. 231.

17 Ibidem, s. 229.

18 J. BAJDA, Grzech ekologiczny (Próba podejścia do zagadnienia), op. cit., s. 73.

19 Ibidem, s. 78.
} 
ścijaństwa: wiarę, nadzieję i miłość, z których jak wiemy miłość jest najważniejsza, w drugiej zaś: roztropność, umiarkowanie, męstwo i sprawiedliwośćc ${ }^{20}$. W etyce filozoficznej natomiast autorzy koncentrują się przede wszystkim na cnotach kardynalnych, których proweniencja sięga filozofii starożytnej, przede wszystkim zaś filozofii Platona i Arystotelesa ${ }^{21}$.

W paragrafie tym zajmę się tylko tymi spośród całego katalogu cnót, które $\mathrm{z}$ powodzeniem można wykorzystać w chrześcijańskiej etyce środowiskowej i edukacji ekologicznej. Niewątpliwie do nich zaliczyć należy teologiczną cnotę miłości oraz kardynalne cnoty roztropności i umiarkowania, które należy od najmłodszych lat upowszechniać w wychowaniu ekologiczno - moralnym chrześcijanina.

Cnota roztropności określana jest jako umiejętność prawego rozumu rozpoznawania i wybierania najwłaściwszych sposobów postępowania. Teolodzy zauważają, że „dzięki tej cnocie wpada się na właściwy trop, czyli wynajduje się najwłaściwszy środek do celu i najodpowiedniej się postępuje"22.

Cnota roztropności w etyce pojmowana jest jako warunek dla zaistnienia innych cnót, ponieważ bez roztropności w zasadzie niemożliwe jest ich zaistnienie, gdyż właściwą miarę może odczytać jedynie rozum. Regułą bowiem dla dobra i zła nie jest w zasadzie przepis, lecz obdarzony roztropnością człowiek. Przepisy bowiem cechuje ogólność, natomiast w działaniu chodzi o dobro konkretne, które właściwie należy odczytač ${ }^{23}$.

Nic dziwnego, że chrześcijańscy moraliści uważają, że degradacja przyrody wynika $z$ degradacji moralnej i duchowej współczesnego człowieka. Cnota roztropności w wymiarze ekologicznym pozwala na oszczędne i przemyślane korzystanie z dóbr naturalnego środowiska, zgodne z wolą Stwórcy. Poza tym prowadzi również do sprzeciwu i dezaprobaty tych wszystkich działań, które prowadzą do degradacji środowiska społeczno - przyrodniczego ${ }^{24}$.

Jednak cnotą, która już z samej definicji, idealnie pasuje do idei chrześcijańskiej etyki środowiskowej jest cnota umiarkowania. Już w starożytności zauważono konieczność nadawania rozumnego umiaru przeżywaniu przyjemności zmysłowych. Cnotę umiarkowania ujmuję w tym paragrafie przede wszystkim jako cnotę ogólną, gdyż „w każdej cnocie wy-

20 C. J. WICHROWICZ, Zarys teologii moralnej w ujęciu fomistycznym, Kraków 2002, s. 107.

21 P. JAROSZYŃSKI, Etyka - dramat życia moralnego, w: M. A. Krąpiec, S. Kamiński, Z. J. Zdybicka, A. Maryniarczyk, P. Jaroszyński, Wprowadzenie do filozofii, Lublin 2003, s. $540-574$.

22 C. J. WICHROWICZ, Zarys teologii moralnej w ujęciu tomistycznym, op. cit., s. 171.

23 P. JAROSZYŃSKI, Etyka - dramat życia moralnego, op. cit., s. 552.

24 S. DZIEKONSSKI, Wychow'anie ekologiczne w religii chrześcijańskiej, w: Podstawy kultury ekologicznej, op. cit., s. 69. 
stępuje jako istotny element pewien umiar, zaprowadzany w uczuciach lub działaniach. A ponadto tylko $\mathrm{w}$ atmosferze umiarkowania wszystkie inne cnoty mogą się odpowiednio rozwijać i dojrzewać"25.

Ekologiczny wydźwięk cnoty umiarkowania pozwala "zahamować nadmierną konsumpcję, która jest wynikiem działania w sposób nieuporządkowany pierwotnych popędów ludzkich i przyczynia się do zakłócenia równowagi ekologicznej. Wychowanie tej sprawności moralnej wydaje się być ważne szczególnie współcześnie, gdy potrzeby człowieka, związane $z$ egzystencją, wywierają coraz większy negatywny wpływ na środowisko naturalne, między innymi przez rabunkową eksploatację ziemi, brak szacunku dla życia ludzkiego, wyniszczenie niektórych gatunków zwierząt i roślin, wywołanie «efektu cieplarnianego». Wobec tego współczesna cywilizacja musi dostrzegać konieczność mądrego, umiarkowanego gospodarowania dobrami materialnymi, czyli takiego, które opierałoby się na zasadach etycznych"26. Bez należytego wprowadzenia cnoty roztropności i umiarkowania w życie zrównoważony rozwój będzie fikcją.

W miejscu tym chciałbym zasygnalizować jeszcze jedno zagadnienie. Chrześcijańska etyka środowiskowa podkreśla, iż wartością autoteliczną jest człowiek, zaś jego godność stanowi w tym systemie normę moralną. Nie znaczy to jednak, że przyroda nie zasługuje na ludzki szacunek. $\mathrm{Na}$ ogół chrześcijańscy moraliści uważają, iż powinność domagania się szacunku dla człowieka jest jednocześnie podstawą szacunku dla środowiska przyrodniczego. Postulują przy tym, aby wszelkie relacje osobowe afirmujące ludzką godność wspierać na przykazaniu „miłuj bliźniego swego jak siebie samego". Miłość bowiem w chrześcijaństwie, jako nadrzędna wartość i pierwsza z cnót teologicznych jest klamrą spinającą inne cnoty. Stanowi bowiem najwyższe kryterium godności osobowej - człowieka ${ }^{27}$ - regulując nasze postępowanie $\mathrm{w}$ stosunku do drugich, $\mathrm{w}$ tym i do środowiska przyrodniczego.

\section{Dekalog ekologiczny}

Jak wcześniej ukazałem w wielu miejscach na kartach mojej rozprawy, niszczenie przyrody w chrześcijańskiej etyce jest grzechem ciężkim i godnym potępienia, a nie tylko nierozsądnym zachowaniem się. W związku z tym poczyniono różne próby opracowania swoistych przykazań ekologicznych, które nawiązywałyby do autorytetu biblijnego Dekalogu.

C. J. WICHROWICZ, Zarys teologii moralnej w' ujeciu tomistycznym, op. cit., s. 267-268.

26 S. DZIEKOŃSKI, Wychowanie ekologiczne w religii chrześcijańskiej, op. cit., s. 69-70.

27 Por. K. WOJTYŁA, Cztowiek w polu odpowiedzialności, Rzym - Lublin 1991, s. 54; W. SŁOMKA, Podmiotowy charakter osoby - godność czlowieka, w: Być człowiekiem, Poznań 1974, s. 85. 
W celu zapobieżenia degradacji przyrody na konferencji Żydów i chrześcijan w październiku 1982 roku, opracowano dziesięć przykazań ekologicznych (Dekalog ekologiczny). Oto one:

1. „Jam jest Pan Bóg twój, który stworzył niebo i ziemię.

Weź pod uwagę, że $w$ tym stworzeniu jesteś moim partnerem.

Obchodź się więc troskliwie z powietrzem, wodą, ziemią

i zwierzętami, tak jakby byli to twoi bracia i siostry.

2. Weź pod uwagę, że dając ci życie, dałem ci także odpowiedzialność, wolność i ograniczone rezerwy surowców ziemi.

3. Nie okradaj przeszłości. Szanuj swoje dzieci, dając im możliwość długiego życia.

4. Rozbudzaj w swoich dzieciach miłość do natury.

5. Rozważ, że ludzkość może wprawdzie używać technologii, lecz raz zniszczonego życia nie może stworzyć na nowo.

6. Zatroszcz się o to, aby $w$ twojej wsi, twoim mieście, twoim kraju tworzyły się grupy, które będą się z zaangażowaniem starały o to, aby zapobiec grożącym katastrofom.

7. Odsuń się od wszelkich broni, które powodują nie dające się naprawić zniszczenia w podstawowych uwarunkowaniach życia.

8. Ćwicz samodyscyplinę także przy małych decyzjach w swoim życiu.

9. Znajdź w twoim cotygodniowym dniu wypoczynku - sabacie czy niedzieli - czas, aby żyć ze światem, a nie tylko go używać.

10. Pomyśl o tym: nie posiadasz ziemi - jesteś tylko jej stróżem (opiekunem)" ${ }^{\prime 28}$.

Dekalog ten jest świadectwem stosunku Kościoła do problemów ekologicznych i zarazem zachętą dla wszystkich chrześcijan, Żydów oraz wyznawców innych religii, aby poważnie potraktowali potrzebę ochrony przyrody. Tego najlepszym wyrazem był wielki, światowy kongres głównych religii świata, który miał miejsce w 1986 roku w Asyżu. Zgromadzeni tam przedstawiciele różnych religii doszli do wniosku, że ochrona przyrody powinna stać się pierwszoplanowym problemem teologicznym, również w wymiarze ekumenicznym.

\section{Zakończenie}

Moim zdaniem wyjście z ekologicznego impasu powinno wspierać się na odpowiednim kształtowaniu postawy moralnej człowieka odnośnie jego przyrodniczego środowiska. W miejscu tym widać jak wielkie mogą być korzyści z zastosowania podstawowych prawd katolickiej teologii moralnej $\mathrm{w}$ wychowaniu ekologicznym społeczeństwa, którą należy upowszechniać w rodzinie i w szkolnictwie - zwłaszcza za sprawą katechezy.

28 J. BOHDANOWICZ, Ku cywilizacji ekorozw'oju, Gdańsk 1998, s. 39-40. 


\section{Ecological aspects of catholic moral theology}

\section{SUMMARY}

Ecological aspect of catholic moral theology should not evoke astonishment as it is not a strange hybrid created by means of artificial manipulations aiming at bestowing authority of Christian tradition on ecology. Popes' statements concerning natural environment conservation seem to testify against such claims and only show the importance and need of implementing responsible and moderate using the Earth's resources into the Christian awareness.

Practical ethical problems in ecological aspect I started to present from the natural law, which determines divine moral order in the world, also in ecological dimension. Then I undertook the problem of ecological conscience, which is a kind of a "watchman" of our morality, also as far as human actions in the natural environment are concerned, and it tries to protect the human being from committing an ecological sin, which is one of the forms of disobedience to God. These ecological aspects of moral theology will remain just hot air if we do not spread them by means of ecological education. It is also very important shape proper and fixed attitudes towards other people and nature that can be described in terms of love, prudence and moderation as aretology (field of science concerning virtues)teaches us. At the end of this paragraph I put Ecological Decalogue, whose rules Christians should obey in everyday life. 